\title{
Studies on the biogenesis of fusaric acid
}

\section{Doctoral Thesis}

Author(s):

Sandhu, Rajindar S.

Publication date:

1959

Permanent link:

https://doi.org/10.3929/ethz-a-000113916

Rights / license:

In Copyright - Non-Commercial Use Permitted 
Prom. Nr. $2956 \varnothing$.

\title{
Studies \\ on the Biogenesis of Fusaric Acid
}

\author{
THESIS \\ PRESENTED TO \\ THE \\ SWISS FEDERAL INSTITUTE OF TECHNOLOGY \\ ZURICH
}

FOR THE DEGREE OF DOCTOR OF NATURAL SCIENCES

BY

RAJINDAR S. SANDHU

CITIZEN OF INDIA

Accepted on the Recommendation of

Prof. Dr. E. Gäumann and Dr. H. Kern

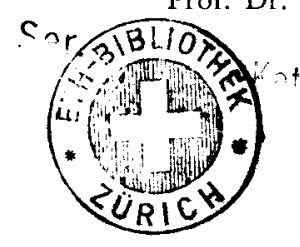

1959

Druck von A. W. Hayn's Erben, Berlin West 
supply of $\gamma$-aminobutyric acid, lysine and $\beta$-alanine. In isotopic competition experiments the latter two did not contribute carbon to fusaric acid. Thus, their role may be either of nitrogen donors or of simple stimulators in the biogenesis of fusaric acid. $\gamma$-Aminobutyric acid, however, contributed its carbon as shown by reduction in the radioactivity of fusaric acid when it was added as inactive competitor to the cells fermenting on active glucose.

It has been shown that $\alpha$-alanine, serine and acetate contribute carbon to fusaric acid. $\alpha$-Alanine and serine are particularly efficient donors of carbon, conversion of their specific activity was about 28 percent when supplied in labelled form to the mycelium fermenting on inactive glucose. Thus, the consideration of $\alpha$-alanine and serine as near precursors of fusaric acid is strongly suggested by these results. Acetate-1-C $C^{14}$ showed about two third as much conversion of its activity into fusaric acid as the other two amino acids. It might be concluded that acetate contributed carbon to only a specific part of the fusaric acid molecule. $\gamma$-Aminobutyric acid-1-C ${ }^{14}$ was found to be less than half as efficient as $\alpha$-alanine or serine in its incorporation into fusaric acid. However, in isotopic competition it exceeds all the other amino acids in lowering the radioactivity of fusaric acid. It is likely therefore that its carbon other than the carboxylic atom plays the real role in the biosynthesis of fusaric acid.

Fusaric acid, being a pyridine derivative with a 10 carbon skeleton, possesses a relatively elaborate molecular structure. It is, therefore, difficult to speculate how exactly simple metabolites like $\alpha$-alanine, serine, $\gamma$-aminobutyric acid and acetate take part in its biosynthesis. Similarly, in higher plaḥts smaller units originating from substances like alanine and glycine are thought to give rise to the pyridine ring (GRIMSHAw and MARION 1958) but no concrete scheme has so far been put forward which could describe this biosynthetic process. MARTIN and Foster (1958) after doing isotopic studies on Bacillus megaterium, have conceived a process of direct ring closure between pyruvate and aspartate or between alanine and oxalacetate. The resulting intermediate is then thought to lose two atoms of hydrogen to give rise to dipicolinic acid. It is indicated by the present studies that some such simple mechanism works for the biosynthesis of fusaric acid. The viewpoint that pyridine ring is evolved through more than one pathway in various biological systems (YANOFSKY 1955, GRIMSHAW and MARION 1958, MARTIN and FOSTER 1958), finds further support in the present investigations.

\section{Summary}

1. A study has been made of the amino acid metabolism of $F$. lycopersici in relation to its fusaric acid production in standing cultures. The amino acids of the mycelium and culture filtrate were measured by paper chromatography. Extraction of the amino acids from the culture filtrate was made by means of Dowex 2 and Dowex 50 ion exchange resins. 
2. Previously synthesized amino acids were observed to be reutilized by the fungus between 14 and 17 days of incubation. Simultaneously the production of fusaric acid was increased. $\alpha$-Alanine and glutamic acid played a prominent role during this phase primarily because of their presence in quantitative preponderance over the other amino acids.

3. The influence of various amino acids on the production of fusaric acid has been investigated by means of washed mycelial mats of $F$. lycopersici and also by the washed cells of Gibberella fujikuroi, grown in shake cultures. In these experiments $G$. fujikuroi gave better results because it synthesized appreciable amounts of fusaric acid in shake culture while $F$. lycopersici failed to do so.

4. The washed cells produced three times more fusaric acid in the presence of glucose than they did in its absence. Out of the many amino acids added to the fermenting cells, only $\beta$-alanine, $\gamma$-aminobutyric acid and lysine succeeded in further increasing the production of fusaric acid.

5. Feeding of glucose-C $\mathrm{C}^{14}$, generally labelled, to the washed cells resulted in the synthesis of radioactive fusaric acid with about 50 percent specific radioactivity of the supplied glucose. Inactive compounds, various amino acids and other metabolites, were added to the culture medium along with labelled glucose (isotopic competition). As a result a significant dilution was obtained in the radioactivity of the synthesized fusaric acid with some of these metabolites for example $\gamma$-aminobutyric acid, $\alpha$-alanine, serine and acetate.

6. The radioactivity of $\alpha$-alanine- $C^{14}(G)$ and serine- $C^{14}(G)$ was readily incorporated into fusaric acid. To a lesser extent acetate- $1-\mathrm{C}^{14}$ was utilized in the biosynthesis of fusaric acid while the participation of glycine-2- $\mathrm{C}^{14}$ and $\gamma$-aminobutyric acid-1-C ${ }^{14}$ was only slight. The radioactivity of fumaric acid-2,3-C ${ }^{14}$ did not appear in the synthesized fusaric acid.

7. It has been concluded that $\alpha$-alanine, serine, $\gamma$-aminobutyric acid and acetate acted as the precursors of fusaric acid though the exact manner of their participation in the biosynthesis of fusaric acid is still unknown.

\section{Zusammenfassung}

1. Die Zusammenhänge zwischen der Fusarinsäurebildung und dem Aminosäurenstoffwechsel wurden in Standkulturen von Fusarium lycopersici untersucht. Die Aminosäuren aus dem Mycel und aus dem Kulturfiltrat wurden papierchromatographisch verglichen. Vor dem Chromatographieren wurden die Aminosäuren des Kulturfiltrats an Ionenaustauschern getrennt.

2. Vom Pilz synthetisierte Aminosäuren (vor allem $\alpha$-Alanin und Glutaminsäure) wurden nach 14 bis 17 Tagen Inkubationszeit wieder in den 
Stoffwechsel einbezogen; zu dieser Zeit stieg auch die Fusarinsäureproduktion an.

3. Der Einfluß verschiedener Aminosäuren auf die Fusarinsäurebildung wurde an Hand von Untersuchungen an gewaschenen Myzeldecken von $F$. lycopersici und gewaschenen Zellen von Gibberella fujikuroi in Schüttelkultur verfolgt. Im Gegensatz zu F. lycopersici bildete G. fujikuroi auch in Schüttelkulturen bedeutende Mengen Fusarinsäure.

4. Bei Versuchen über wenige Stunden vermochte Glukose die Fusarinsäurebildung von gewaschenem Myzel um mehr als das Dreifache zu steigern. Von vielen geprüften Aminosäuren führten nur $\beta$-Alanin, $\gamma$-Aminobuttersäure und Lysin eine weitere Steigerung herbei.

5. Bei Verfütterung von Glukose-C ${ }^{14}$ wurde Fusarinsäure von der halben spezifischen Aktivität der eingesetzten Glukose gebildet. Wurden auch inaktive Komponenten (z. B. Aminosäuren) zusammen mit markierter Glukose in die Kulturlösung gegeben (Methode der Isotopenkonkurrenz), so fand eine merkliche Verringerung der Radioaktivität der Fusarinsäure durch Zugabe folgender Metaboliten statt: $\gamma$-Aminobuttersäure, $\alpha$-Alanin, Serin und Acetat.

6. Die Radioaktivität von $a$-Alanin- $\mathrm{C}^{14}$, Serin- $\mathrm{C}^{14}$ und zu einem kleineren Teil auch von Acetat-1-C $\mathrm{C}^{14}$, wurde in die Fusarinsäure eingebaut. Glykokoll-2-C ${ }^{14}$ und $\gamma$-Aminobuttersäure-1-C ${ }^{14}$ lieferten nur sehr wenig und $\mathrm{Fu}-$ marsäure-2.3-C $\mathrm{C}^{14}$ überhaupt keinen radioaktiven Kohlenstoff zur Bildung der Fusarinsäure.

7. Aus den Versuchen darf geschlossen werden, daß $\gamma$-Aminobuttersäure, $\alpha$-Alanin, Serin und Acetat an der Biosynthese der Fusarinsäure beteiligt sind. In welcher Weise der Aufbau des Toxins erfolgt, läßt sich jedoch heute noch nicht entscheiden.

Sincere thanks are expressed to Professor Dr. E. GÄUmann, Director of the Department of Special Botany of the Swiss Federal Institute of Technology, for his consistent encouragement and advice in the execution of this work. The writer is grateful to Dr. H. KERN for his interest and numerous suggestions. The help of Dr. Robert N. GOODMAN in the preparation of the manuscript is acknowledged. The writer is also grateful to all his colleagues in the laboratory for their help. Some of the preliminary work, particularly in the methodological part, has been based on unpublished studies by Miss M. Pavoni.

The writer is indebted to the authorities of the Swiss Coordination Commission for Technical Help for the grant of a fellowship during the period from March, 1957 to August, 1959. The studies with radioactive isotopes were made possible by a generous grant of the „Fritz Hoffmann-La Roche-Stiftung zur Förderung wissenschaftlicher Arbeitsgemeinschaften in der Schweiz". 